\title{
Trade Openness and Economic Growth in Nigeria: Further Evidence on the Causality Issue
}

\section{Saibu Muibi Olufemi}

Department of Economics, Obafemi Awolowo University

\begin{abstract}
The study specifically investigated the causality between the openness variable and economic growth, using data from the Nigerian economy. Previous studies in Nigeria have interpreted the regression results of output variables on the export trade variable as providing support for trade liberalization as engine for growth with less emphasis on other measures like import. Such an interpretation is questionable, since these regressions provided no means for determining the direction of causality. This paper performed causality tests with various forms of openness measures and economic growth. The results indicated a unidirectional relationship between openness and growth. This shows that an increasing level of openness will be beneficial, depending on the level of economic development in Nigeria. The result is robust across different measures of openness and analytical techniques.
\end{abstract}

JEL F14, 43

\section{INTRODUCTION}

The idea that trade openness affects economic growth is not new again. However, the nature of the effect is being seriously debated in the literature. Some empirical studies have identified a positive linkage between a country's rate of economic growth and its openness to international trade, while others have failed to demonstrate such linkage, (Jin, 2002; Sinha \& Sinha, 1996). The crux of the differences in these results has been the differences in methodology as well as the way the openness variables were defined (Baldwin, 2002 and Ajayi, 2003).

Most striking fact about the existing volume of studies is that despite the fact that both exports and imports are equally important in promoting economic growth, most researchers have focused attention on the former (Sinha \& Sinha 2003, Jonsson \& Subramanian, 2001). A developing country like Nigeria is 
import dependent, therefore, its import effects on the growth process should not be ignored or assumed away without any empirical basis. Also, Nigeria has experimented with different exchange rate regimes, which might have implications for the trade-growth nexus. More importantly, with exception of Odusola and Akinlo (1995), no other studies on the Nigerian economy examined the causal relationship between trade (openness) variables and economic growth. The neglect of the causality nexus has implication on the correct modeling of the trade-growth equation. A causality test could provide insight on whether a single or simultaneous equation model is appropriate for trade-growth relationship. The fact that trade volume and economic growth are in tandem revealed nothing about the causal direction. Therefore, the issues of causality between trade and economic growth need to be investigated.

This paper essentially contributes to existing studies in three ways: First, the paper included new time series from 1993 to 2000, which were excluded in the earlier studies on the Nigerian economy. The period of 1993 to 2000 coincided with the period when the external trade and exchange rate were extensively liberalized (see figures $1 \& 2$ ) and thus could have implication on the empirical results. Second, rather than using the common narrow definition of openness, this paper used a variety of measures of trade openness and this helped to check the robustness of the causality results. Third, both VECM and standard granger causality tests were used. This was done to check whether omission of the error correction channel of influence in the granger causality test has any implication on the results. Therefore, this paper not only extended the existing literature but also improved the quality of the evidence.

The structure of the paper is as follows. Section 2 examined the trend of trade openness and economic growth over the years. Section 3 provided a review of the existing studies. Section 4 presented the methodology while section 5 analyzed the empirical results. Section 6 concluded the paper with policy implications of the findings.

\section{TRADE OPENNESS AND ECONOMIC GROWTH IN NIGERIA}

The analysis of the growth of exports and imports gives an indication as to the extent of the openness of an economy. However, trade flow analysis provides the basis of robust empirical investigation of the openness of an economy. Empirically, openness can be measured by the share of trade (import plus export) in total output, measured by the Gross Domestic Product (GDP). This is a broad concept of openness; in the narrow context, the ratio of imports or exports to GDP can represent the degree of openness of an economy. 
A cursory look at Figure 1 shows that the Nigerian economy has been relatively more open since 1986, as a result of policy measures applied under the structural adjustment programme. The broad measure of openness, total trade to GDP (TT/GDP) increased from 0.21 in 1986 to 0.64 in 1987 as a result of the consistent implementation of adjustment measure. In 1990, there was an upward trend in openness when the index reached 1.72. The situation further improved from 1995 when the index rose to about 17.0 because of a policy of deregulation that was re-introduced. The most important factor responsible for the upsurge in the trade volume and the phenomenal increase in the openness index was the final removal of other restrictions on trade as a final measure of the Nigerian government in becoming a member of the World Trade Organisation (WTO) in 1995. This led to increased trade relations with other countries. At the end of 1999, the index of openness reached a remarkable level of 17.6 from 1.1 in 1989.

Figure 1 Aggregate output growth and trade openness in Nigeria, 19702000

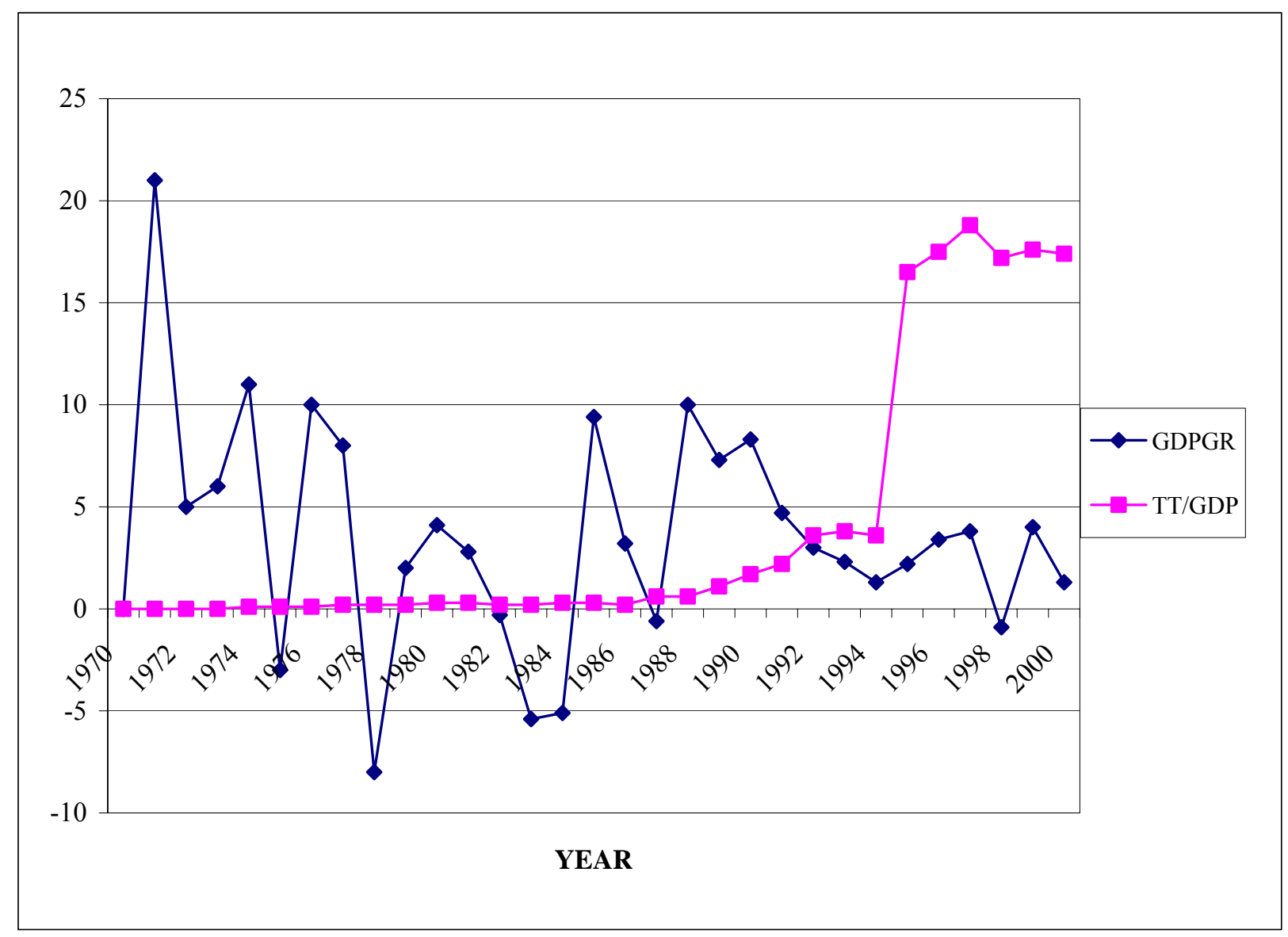


While the economy has recorded remarkable progress in improving trade relations with other countries as reflected by the increasing rate of total trade to GDP, the rate of economic growth has remained sluggish. The low correlation depicted by the graph between the openness of the economy and the growth rate of the economy showed that openness has not contributed much to economic growth in Nigeria. In other words, Nigeria has not benefited as expected from the liberalization of the economy. Though, the above trend analysis is informative and indicative of the inverse relationship between economy growth and external trade in Nigeria, definite statements cannot be made without any empirical basis. The subsequent sections examined the empirical relationship between economic growth and openness in Nigeria.

\section{REVIEW OF RELATED STUDIES}

The relationship between openness and economic growth in developing economies has been fully analyzed by a large number of empirical papers. Primary attention has been given to the role of exports in economic performance with little attention paid to other growth promoting openness variables. In their paper, Cuadros, Orts and Alguacl (2001) employed a VAR model to examine the causal relationship between output level, inward Foreign Direct Investment (FDI) and trade in Argentina, Brazil and Mexico. They found that though FDI had significant impacts on growth, their results failed to find evidence in support of export led growth. They concluded that the fragility of their result may stem from the omission of other relevant mechanism through which openness can promote growth. Similarly, Goldberg and Klein (1999) had also opined that if capital flow is significant, focusing only on export as proxy for openness may be misleading. Using data from some Asian countries, Sinha and Sinha (2001) also reiterated that omitting import from trade openness measure creates a missing variable bias. Using data from imports and exports to capture openness, they found positive effects of openness on economic growth for some Asian countries.

Apart from export, other trade measures have gained prominence in the literature in recent times. For example, Chanda (2001) used an index of capital account openness to show that more developing countries have suffered from opening their economies than not, while Rodrik (1998) as well as Alesina et al. (1994) found no effects of capital account openness on economic growth. With respect to FDI, there is evidence of a positive growth-effect in countries that are sufficiently rich (Blomstriom et al., 1992, Zhang, 2002; Alfaro \& Chanda, 2001) and a negative one in low-income countries (Garrett, 2001). Also, Carkovic and Levine (2002) did not find a robust influence of FDI on growth. Studies examining the effects of FDI on countries growth rates, summarized by 
Durham (2000), were not unanimous in their findings. Similarly, Edison et al. (2002) detailed analysis of the impact of several indicators of financial openness on growth, showed that no robust relationship exists. However, Dreher (2002) using different measures of openness to capture economic globalization found that globalization promote growth but not to the extent that it can reduce poverty.

Studies carried out on Nigeria using time series data, has been scanty. Egwaikhide (1994) examined the link between the trade variable (export) and economic growth in Nigeria between 1959 and 1989, using cointegration and error correction methods. This approach is appealing as it could eliminate the problem of spurious estimates, which previous studies ignored. Ekpo (1995) also examined the openness and performance of the Nigerian economy for the period 1970 to 1992 using broad measures of openness. Using the aggregate production model, his analysis showed that capital stock and labour contributed positively to output growth during the period. However an increase in trade share measured by the black market premium rate and trade/GDP respectively, reduced output.

Oladipo (1998) extended the Ekpo and Egwaikhide (1994) model. He measured the degree of openness as the ratio of total trade (export + import) to GDP and as the ratio of export to GDP. Based on a sample period of 27 years (1970 to 1996), Nigerian quarterly data, the results showed that when the export/GDP ratio was used as a measure of openness it correlated positively with GDP growth. But, the conventional broad measure (import plus export) to GDP indicated a negative relationship. Olomola (1998) used the endogenous growth model to explore the long-run relationship between openness and economic growth. He adopted Dickey-Fuller and Augmented Dickey-Fuller test to examine the stationarity properties of the variables. Openness was proxied by export/GPD and total trade/GDP for sample period of 1960 to 1998, he found that total trade/GDP, has no significant relationship with long run growth in Nigeria.

In recent studies, Akinlo (2003a,b) examined the effects of FDI on economic growth in Sub-Saharan Africa. He found out that FDI had a positive impact on Sub Saharan African economic growth. In addition, both export and stock market development had positive effects. Though, this result is indicative of the possible role openness in the form of inward flows of capital goods could play in a developing sub-Saharan African country, the fact that the analysis was based on panel data makes country specific policy inferences difficult from the evidence. It is possible that individual country result may differ if time series data are employed. Apart from this shortcoming, one other important shortcoming of these studies is that they ignored the causal relationship between 
trade openness and growth. Their outcomes were monumental but the neglect of the nature and direction of influence between the trade variable and growth, made their results tentative.

Some studies have attempted addressing the issue of causality between the trade variable (especially export) and economic growth. Jung and Marshall (1985) used time series data to perform Granger (1969) causality tests between export and growth for 37 developing countries. The results provided evidence in favour of export led growth in only four instances. The result showed that the export promotion hypothesis is weaker than what previous statistical studies have indicated. Kunst and Mario (1989) also investigated the causality between productivity and exports using quarterly data for the period between 1965 and 1985. The result indicated no causal link from export to productivity.

Muhammed and Sampath (1999) also empirically examined the causality between exports (as a measure of trade openness) and economic growth for 97 countries using data for the period 1960 to 1992. While determining the stationarity of the two variables and their order of cointegration, they found that GDP and exports are integrated of different orders for 36 countries. Among the other 61 countries, for 17 countries, there were no long-run relationship between the two variables, 35 countries showed causality at least in one direction. Uni-directional causality from GDP to exports was reported for 10 countries, from export to GDP for 5 countries and bi-directional causality for 20 countries. Nine (9) countries did not show any causality between GDP and exports at all. One important issue of relevance to this study, is that Nigeria was among the 9 countries without causal relationship between exports and economic growth. The findings were contracted from existing studies. Anoruo and Ahmad (1999) used Johansen's (1991) cointegration technique instead of the Granger (1969) causality test to examine the causal link between trade openness and economic growth. In the five (5) Asian countries, selected covering 1960 to 1998, they found that both openness variables and economic growth are cointegrated and that there was a bi-directional causality between trade openness and economic growth.

Our perusal of literature on Nigeria has not indicated any detailed effort at investigating the causal link between trade variables and economic growth. The only exception was Odusola and Akinlo (1995). They used the traditional Granger (1969) causality test to examine the causal relationship between openness and GDP growth. The set of trade variables considered were export, import, and terms of trade and factor inputs, proxied by gross capital formation and labour force, using Nigerian data over 32 years from 1960 to 1992. The causality analysis using the Granger (1969) test indicated bi-directional causal effects between export and growth, there was a unidirectional relation between 
terms of trade and exports while imports had causal effects on capital formation only. This result contradicted the Muhammed and Sampath (1999) result on Nigeria despite using the same causality test. However, Odusola and Akinlo's (1995) traditional Granger causality test suffered from two methodological deficiencies.

First, the standard test adopted did not examine the basic cointegration properties of the variables. If the variables were cointegrated, their model which incorporated the difference variables, is mis-specified since the lagged error correction term is not included (Granger, 1988). Second, the noninclusion of the error correction term from the cointegration equation eliminated the long-run information embodied in the original form of the variables. The exclusion of the error correction term also foreclosed the detection of an additional channel of Granger causality through the lagged error correction terms. In view of this, Odusola and Akinlo's (1995) result could not be regarded as final and conclusive. It would, therefore, be interesting to reexamine the causality between trade openness and economic growth through the yet to be explored (error correction term) channel using data from Nigeria.

The fact that none of the existing studies was categorical about the nature and direction of the relationship between trade openness and economic growth makes further analysis imperative. Most importantly, the methodology adopted in these studies cannot capture the complex interrelationship between trade and economic growth. It cannot show the likely long run (feedback) effects that exist among trade variables and economic growth. This paper therefore addressed this empirical issue by employing Johansen (1991) cointegration and VECM procedure (in addition to the standard Granger causality test) with time series data for Nigeria and a larger set of trade variables. This method has been found to perform better than the Granger $(1969,1980)$ causality approach (Anorou \& Ahmed, 1999).

\section{DATA AND METHODOLOGY}

This study used annual data on gross domestic product (TGDP), industrial output (INDGDP) and openness measured by a set of trade openness variables for Nigeria. The data cover the period 1970 through 2000. The openness variable was proxied by a set of five (5) variables: export (EXPT), import (IMPT), and export plus import (TTRADE), exchanges rate premium (EXRT) and net capital inflow (NFCI). Indeed, we are aware of the criticism of using trade volume instead of trade policy as measures of openness (Rodriquez and Rodrik, 1999; Rodrik, 1999 and Jonsson \& Subramanian, 2001). As Rodrik also observed, most of the trade policy measures in developing countries, like 
Nigeria, are of low quality and unreliable. Also Jonsson and Subramanian (2001) had argued that trade openness has two forms, namely trade outcomes and trade liberalization. In view of the inadequate and unreliable consistent time series data in Nigeria trade outcomes measures become more appropriate. Therefore, this paper utilizes the trade outcome to measure openness. All the data are collected from Statistical Bulletin and Annual Report and Statement of Account published by Central Bank of Nigeria (CBN, 2001).

Cointegration procedure requires time series in the system to be non-stationary in their level. Similarly, it is imperative that all time series in the cointegrating equation have the same order of integration. Consequently, the study first ascertained the time series properties of all the variables. We employed the augmented Dickey-Fuller test for stationarity; the equation estimated for the Augmented Dickey-Fuller test is as follows:

$$
\Delta x_{t}=\alpha_{t}+\beta_{1} x_{t-1}+\partial t+\sum_{i=1}^{n} \theta_{i} \Delta x_{t-1}+\ell_{t} \ldots 1
$$

Where, $\Delta$ is the first-difference operator; $\mathrm{t}$ is the time trend, and $\ell_{\mathrm{t}}$ is the stationary random error, $\mathrm{n}$ is maximum lag length. $\mathrm{X}_{\mathrm{t}}$ is total output (tgdp), industrial output (indgdp), and export (expt), import (impt), exchange rate premium (exrt), net capital inflow (nfci) and sum of import and export (ttrade),.

To ascertain the long run relationship between economic growth and openness, the Johansen cointegration procedure is utilized (Johansen, 1991) and Johnsen and Juselius (1990). The procedure involves the estimation of a vector errorcorrection model (VECM) in order to obtain the likelihood-ratios (LR). The VECM used in the study is as follows:

$$
\Delta y_{t}=\theta_{0}+\sum_{i=1}^{m} \theta_{i} \Delta y_{t-i}+\alpha \beta^{\prime} y_{t-k}+\ell_{t} \ldots 2
$$

Where, $\Delta$ is the difference operator, $\Delta \mathrm{Y}$ is total output (GDPt), industrial Output (indgdp), and export (expt), import (impt), exchange rate premium (exrt), net capital inflow (nfci) and sum of import and export (ttrade)], $\theta_{0}$ represents the intercept, and $\ell_{\underline{t}}$ represents the vector of white noise process. The matrix $\exists$ consists of $r \quad(r<n-I)$ co-integrating vectors. Similarly, the matrix $\forall$ contains the error correction parameters. In equation (2), the null hypothesis is that the matrix $(\mathrm{B}=\forall \exists$ ') has a reduced rank of $\mathrm{r}<\mathrm{n}-\mathrm{I}$. The alternative hypothesis, is that the matrix $\left(\mathrm{B}=\forall \exists^{\prime}\right)$ has full rank. Johansen procedure of cointegration provides two statistics. These include the value of the LR test based on the 
maximum eigenvalue of the stochastic matrix and the value of the LR test based on the trace of the stochastic matrix.

The causal relationship between economic growth-openness is examined with the help of Granger-causality procedure based on VECM. This procedure is particularly attractive over the standard VAR because it permits temporary causality to emerge from (1) the sum of the lagged coefficients of the explanatory differenced variable and (2) the coefficient of the error correction term. In addition, the VECM allows causality to emerge even if the coefficients of lagged differences of the explanatory variable are not jointly significant (Anoruo \& Ahmad, 1999). It must be pointed out that the standard Grangercausality test used in earlier studies (e.g. Odusola \& Akinlo, 1995) omitted the additional channel of influence $\left(\mathrm{z}_{\mathrm{t}-1}\right)$. In this study, the error correction model is based on:

$$
\begin{aligned}
& \Delta g d p_{t}=\alpha z_{t-1}+\sum_{j=i}^{a} \beta_{i} \Delta g d p_{t-1}+\sum_{j=i}^{b} \theta_{j} t r d_{t-1}+\mu_{t} \ldots \ldots .3 \\
& \Delta t r d_{t}=\vartheta z_{t-1}+\sum_{j=1}^{c} \theta_{i} \Delta t r d_{t-1}+\sum_{j=1}^{d} \lambda_{j} \Delta g d p_{t-1}+\ell_{t} \ldots \ldots .4
\end{aligned}
$$

where $\mathrm{z}_{\mathrm{t}-1}$ represents the error correction term lagged by one period, $\mathrm{GDP}_{\mathrm{t}}$ represents tgdp and indgdp, the growth variables, and $\operatorname{trd}_{t}$ stands for the openness variables (i.e. expt; impt; ttrade; nfci and exrt). A, b, c, and d represent the optimal lag lengths obtained from the Final Prediction Error (FPE). All the variables are logarithmic and enter the co-integration analysis in levels.

In equation (3), the rejection of the null hypothesis that openness does not granger cause economic growth, requires that (i) the $\theta_{j}$ be conjointly statistically significant and/or (ii) the error-correction term $\left(\mathrm{z}_{\mathrm{t}-1}\right)$ be statistically significant. Similarly, in equation (4) the null hypothesis that economic growth does not granger cause openness is rejected on the condition(s) that the $\lambda_{j}$ s are jointly significant and/or the error correction term $\left(\mathrm{z}_{\mathrm{t}-1}\right)$ is significant.

\section{EMPIRICAL RESULTS}

Following the steps discussed in section 4, the result of the augmented Dickeyfuller (ADF) unit root tests are presented in Table 5.1. The non-hypothesis of non-stationarity of economic growth and trade openness variables is tested against the alternative hypothesis of stationarity. The results indicated that 
except for industrial output that was stationary at level, all the other series were not stationary in their levels. However, at first difference, the null hypothesis of no unit roots is not rejected as 5 per cent significance level. In all, the results indicated one order of integration for both economic growth and trade openness variables.

\section{Table 5.1 ADF unit root test results}

Unit root tests for stationarity with constant only: 1970-2000

\begin{tabular}{|l|c|c|}
\hline Variables & LEVELS & First difference \\
\hline Ltgdp & -2.286 & -6.211 \\
\hline Lindgdp & -6.926 & -9612 \\
\hline Lexpt & 0.003 & -4.244 \\
\hline Limpt & -0.085 & -3.246 \\
\hline Lexrt & 0.668 & -3.198 \\
\hline Lnfci & -0.997 & -9.235 \\
\hline Lttrade & 0.7169 & -5.402 \\
\hline
\end{tabular}

The critical values at 5 per cent for levels and first difference are 2.967 and -2.971 respectively. The series are; ltgdp = aggregate gross domestic output; lindgdp=industrial output; lexpt=exports; limpt=imports; 1 ttrade=sum of export and import; lexrt=exchange rate premium; lnfci= net capital inflow. All the variables are in log forms.

Having determined the stationarity of time series the next step of our study involved the application of Johansen procedure to ascertain whether trade openness variable are co-integrated with the economic growth variables for Nigerian data. In the bivariate system, consisting of economic growth and trade openness variables, the maximum number of co-integrating vectors is one so the null hypothesis is that there is no co-integrating vector and the alternative is that, there is one co-integrating vector The results of the procedure are presented in table 5.2. The null hypothesis of no co-integration between economic growth variables and trade openness (i.e. $\mathrm{r}=0$ ) is rejected at the 5 percent significant level in all the cases. However, the null hypothesis that there is at most one cointegrating vector $(\mathrm{r} \leq 1)$ could not be rejected for the all the cases. The fact that the economic growth and openness variable are co-integrated for Nigerian economy suggests that (I) there is a long run equilibrium relationship between the time series and (ii) the existence of causality in at least one direction.

Given the results of the co-integration tests, the next step is the estimation of the VECM of equation $3 \& 4$ to determine the direction of causality between economic growth and trade openness variables. The results from the bivariate 
causality tests from the estimates of the VECM were presented in Panel A(i-ii) and $\mathrm{B}(\mathrm{i}-\mathrm{v})$ of Table 5.3. Panel A(i) and A(ii) contain the estimates of growth equation 3 for aggregate output (TGDP) and industrial output (INDPGDP) respectively. The estimates of openness for each openness measure, LEXPT; IMPT; LEXRT; LTTRADE; and LNFCI, accordingly, were presented in Panel $\mathrm{B}(\mathrm{i}-\mathrm{v})$.

Table 5.2 Results of Johansen co-integration test

\begin{tabular}{|l|c|c|c|c||}
\hline \multirow{2}{*}{ Series } & \multicolumn{2}{|c|}{$\begin{array}{c}\text { Maximum Eigen } \\
\text { values }\end{array}$} & \multicolumn{2}{c||}{ Trace statistics } \\
\cline { 2 - 5 } & $\mathrm{H}_{\mathrm{o}}: \mathrm{r}=0$ & $\mathrm{H}_{\mathrm{o}}: \mathrm{r}<1$ & $\mathrm{H}_{\mathrm{o}}: \mathrm{r}=0$ & $\mathrm{H}_{\mathrm{o}}: \mathrm{r}<1$ \\
\hline Lgdp \& Lexpt & 0.747 & 0.001 & $39.840^{*}$ & 0.017 \\
Lgdp \& Limpt & 0.756 & 0.003 & $41.026^{*}$ & 0.082 \\
Lgdp \& Lexrt & 0.175 & 0.016 & $43.664^{*}$ & 0.462 \\
Lgdp \& Lttrade & 0.752 & 0.0001 & $40.462^{*}$ & 0.003 \\
Lgdp \& Lnfci & 0.856 & 0.062 & $49.894^{*}$ & 1.597 \\
\hline Lindgdp \& Lexpt & 0.001 & 0.001 & $36.685^{*}$ & 0.023 \\
Lindgdp \&Limpt & 0.687 & 0.001 & $33.255^{*}$ & 0.042 \\
Lindgdp \& Lexrt & 0.697 & 0.015 & $35.088^{*}$ & 0.431 \\
Lindgdp \& Lttrade & 0.680 & 0.014 & $33.480^{*}$ & 0.396 \\
Lindgdp \& Lnfci & 0.712 & 0.045 & $32.274^{*}$ & 1.151 \\
\hline
\end{tabular}

Rejection of the null hypothesis at 5 per cent significance level.

The critical values for the hypothesis $\mathrm{r}=0$ at $5 \%(1 \%)$ are 15.41 (20.04).

The critical values for the null hypothesis $\mathrm{r}=1$ at $5 \%(1 \%)$ are $3.76(6.65)$.

Table 5.3 F-statistics for the bivariate causality test based on VECM

\begin{tabular}{|c|c|c|}
\hline Series & Joint coefficients & $\begin{array}{c}\text { ECM t- } \\
\text { values }\end{array}$ \\
\hline $\begin{array}{l}\text { PANEL A(i) Growth Equation (3) for } \Delta \text { LGDP: } \\
\qquad \Delta \text { LEXPT } \\
\Sigma \Delta \text { LIMPT } \\
\Sigma \Delta \text { LEXRT } \\
\Sigma \Delta \text { LTTRADE } \\
\Sigma \Delta \text { LNFCI }\end{array}$ & $\begin{array}{l}-0.107 \\
-0.038 \\
-0.289 \\
-0.081 \\
-0.018\end{array}$ & $\begin{array}{c}-3.290^{*} \\
-3.183^{*} \\
-3.638^{*} \\
-3.232^{*} \\
-1.285\end{array}$ \\
\hline 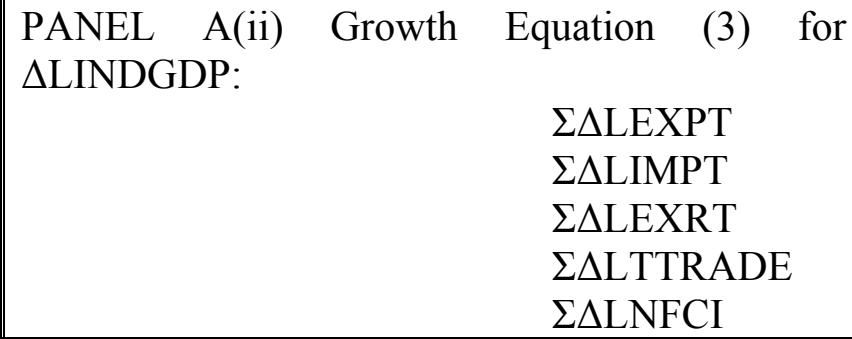 & $\begin{array}{c}0.047 \\
-0.175 \\
0.006 \\
0.005 \\
-0.064 \\
\end{array}$ & $\begin{array}{c}-10913^{*} \\
-11.071^{*} \\
-9.913^{*} \\
-10.134^{*} \\
-10.974^{*}\end{array}$ \\
\hline
\end{tabular}


Table 5.3 continued

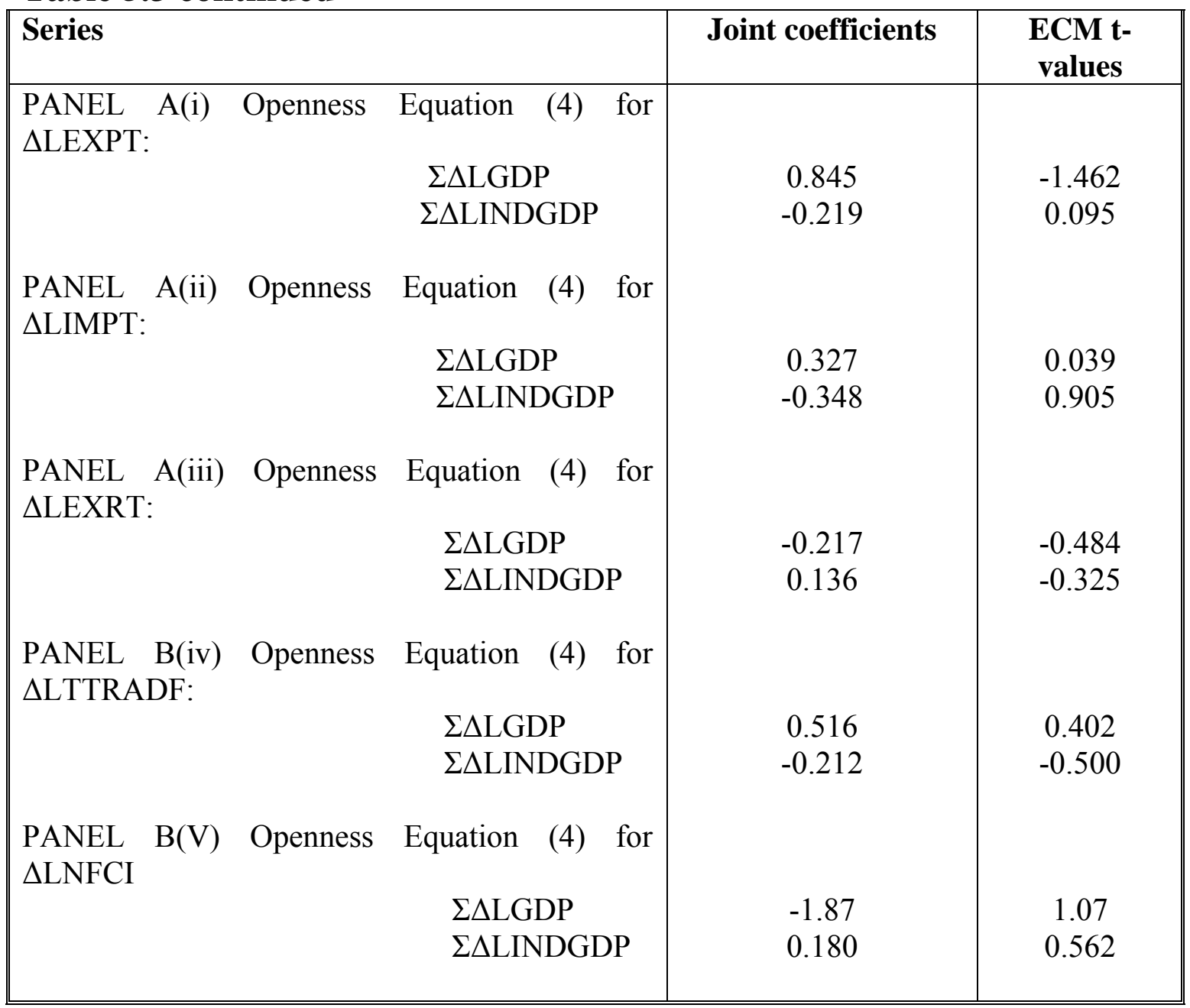

* Represents rejection of hypothesis at 5 per cent of significance. The joint significance of the coefficient is ascertained by the standard F-test. The level of significance for the error correction terms is determined by standard tstatistics.

As could be observed from the Table 5.3, causality is only present in Panel A that is from openness to economic growth, not the other way round. This is evident from the significance of the error correction terms (ECMs) in Panel A and the insignificance of all the ECMs in Panel B. However, there was no causation through the statistical significance of the explanatory variables. As far as the joint significance test applied to the sum of the coefficients of each explanatory variable is concerned, there is no support for causality between trade openness and economic growth. Therefore, the principal source of causality is through the error correction terms, which validated the existence of a long-run equilibrium relationship between economic growth and openness. This result suggested that there is only uni-directional causality from trade openness to economic growth. 
To check the robustness of the results and the implication of excluding ECM terms in modeling variables that were cointegrated, the standard Granger causality test was conducted. As shown in Table 5.4, except for the total trade measure of trade openness, which indicates bi-directional causality, there was no causality from economic growth to other openness variables. Unidirectional causality was indicated from trade measures to aggregate output but no causality was indicated between industrial output and the trade variables. The result from the standard Granger causality test suggested that the causal effects of economic growth on trade is weak in Nigeria, as reported by the VECM method. Thus, the estimates were robust and hence the omission of the ECM term might have resulted in specification bias, if the causality was presented only in the error correction term as observed in this paper.

\section{Table 5.4 Bivariate Granger causality test}

\begin{tabular}{|l|c|c|}
\hline The Null Hypothesis & F-statistics & P-values \\
\hline EXPT does not cause GDP & $4.029^{*}$ & 0.031 \\
GDP does not cause EXPT & 0.094 & 0.910 \\
IMPT does not cause GDP & $3.805^{*}$ & 0.021 \\
GDP does not cause IMPT & 0.413 & 0.666 \\
EXRT does not cause GDP & 2.321 & 0.776 \\
GDP does not cause EXRT & 0.569 & 0.607 \\
TTRADE does not cause GDP & $4.087^{*}$ & 0.030 \\
GDP does not cause TTRADE & $7.323^{*}$ & 0.033 \\
NFCI does not cause GDP & & \\
GDP does not cause NFCI & 2.670 & 0.938 \\
& 0.629 & 0.544 \\
EXPT does not cause INDGDP & & \\
INDGDP does not cause EXPT & 1.400 & 0.267 \\
IMPT does not cause INDGDP & 1.187 & 0.322 \\
INDGDP does not cause IMPT & 1.595 & 0.224 \\
EXRT does not cause INDGDP & 0.189 & 0.829 \\
INDGDP does not cause EXRT & 2.022 & 0.154 \\
TTRADE does not cause INDGDP & 0.066 & 0.936 \\
INDGDP does not cause TTRADE & $12.811^{*}$ & 0.0001 \\
NFCI does not cause INDGDP & $8.072^{*}$ & 0.002 \\
INDGDP does not cause NFCI & 1.868 & 0.181 \\
\hline \hline
\end{tabular}


* Represents rejection of hypothesis at 5 per cent level of significance. P-value means the probability that the null hypothesis could not be true. Critical value of 2.89 at 5 per cent level of significance has been used for the rejection of no causality.

It is interesting to observe also that, the signs on the sum of the coefficients in most of the variables were negative. This implies (Table 5.3) that there is an inverse relationship between the openness variables and economic growth. This also seems contradictory to the generally held view that openness should not only cause but also promote economic growth. The significant negative causal effects of increasing openness on real output growth is consistent with the argument of Aiken and Harrison (1999) and Jin (2002), that increased international competition due to openness may cause domestic investment to decline, and its decrease would be greater than an increase in capital inflows from abroad. If this net investment falls, aggregate demand will follow.

The results indicated further that trade openness or liberalization depressed the growth process in the Nigerian economy. The results are not surprising giving the nature of Nigerian external trade. Most often, the export volume is dominated by crude oil whose price and quantity is determined in the international market and has little or no relation with economic reality in the Nigerian economy. In the case of imports, the volume is skewed towards semiprocessed goods deceitfully packed as raw materials when being imported; this hindered the development of the local industries. There is a high incidence of exchange rate round tripping, a situation where some scrupulous people buy foreign currency at official rate in order to sell it on the black market. As a result, the productive sector was deprived access to foreign currency to procure locally unavailable raw materials. The premium therefore do not reflect the reality in the economy. This consequently depressed the production capacity of the economy rather than promoting it. In fact, the non-causal linkage from economic growth to trade openness indicated that the growth in Nigeria's total trade has nothing to do with Nigerian economic reality. This result thus suggested that increased trade openness might have contributed to the low economic growth in Nigeria in recent times.

\section{SUMMARY AND CONCLUSION}

For the past decade, the relationship between economic growth and openness has been a topic of sustained interest and controversy in economic development literature. This study improved on previous studies done on the Nigerian economy by suggesting a reasonable approach to re-investigating the economic growth openness nexus. Specifically, the study employed the Johansen 
cointegration technique for the long-run relationship between openness and economic growth. Finally, VECM was estimated to capture the permanent and transient movement between the variables contained in the co-integration equations.

The paper found that economic growth and openness were cointegrated for the Nigerian economy, thus there was a long-run relationship between them. Only unidirectional causality from economic growth to trade openness was present. This was corroborated by a standard Granger causality test. Alfaro and Chanda (2002) also argued that openness measured by FDI played an ambiguous role in contributing to economic growth. Countries with a well-developed financial market, benefit from openness while countries like Nigeria with a lessdeveloped financial market, lose more with increasing openness. The trade sector, therefore, could not be excused from the blame for overall low economic performance in Nigeria. In fact, the extensive liberalization of Nigerian external trade without taking cognizance of the economic reality in Nigeria, could have engineered the economic recession experienced in the country in recent times. The import dependent (industrial) sector, which is vulnerable to adverse development in the trade sector, seemed weak to absorb the shocks from disturbances from the international market.

The policy implication that emerged from this study is that, the trade-growth relationship could be model led in a single equation, as no interactive (feedback) nexus exist between trade and growth variables considered in this paper. The Nigerian government also needs to moderate its trade liberalization policy as the economy seems too weak to absorb the negative shocks from external trade. Most importantly, adequate fiscal and monetary policies should be put in place to offset the likely negative effects of exposing the economy to external influences.

\section{REFERENCES}

1 AJAYI, S.I. (2003) "Globalization and Africa" Journal of African Economics, 12 AERC Supplements 1: 120-50.

2 AKINLO, A.E. (2003a) "Foreign direct investment and economic growth in Sub Saharan Africa" International Review of Economics and Business, 50(4): 569-80.

3 AKINLO, A.E. (2003b) "Globalization, international investment and stock market growth in Sub Saharan Africa", final research report submitted to the Institute of Developing Economies, JETRO, Japan.

4 ALESINA, A., VITTORIO, G. \& GIAN MARIA, M.F. (1994) "The political economy of capital controls" in L. Leiderman and A. Razin 
(eds.) Capital Mobility: the Impact on Consumption, Investment and Growth, Cambridge: 289-321.

5 ALFARO, L., CHANDA A., KELEMLI-OZCAN, S. \& SAYEK, S. (2002) "FDI and economic growth: the role of local financial markets", Conference Paper at SED Conference in Stockholm Sweden.

6 BALDWIN R.E. (2002) "Openness and growth what's the empirical relationship", Paper presented at the International Seminar in International Trade (ISIT) Challenges to Globalization May 24-25. Stock.

7 BLOMSTROM, M., LIPSEY, R. \& SEJAN, M. (1992) "What explains developing country growth?" NBER Working Paper 4132.

8 CARKOVIC M. \& LEVINE, R. (2002) "Does foreign direct investment accelerates growth?" Mimeo University of Minnesota.

9 CHANDA, A. (2001) "The influence of capital controls on long run growth: where and how much?", North Carolina State University, Mimeo.

10 CUADROS, A., ORTS, V. \& TALGUACIL, M. (2001) "Openness and growth: Re-examining foreign direct investment, trade and output linkages in Latin America", Center for Research in Economic Development and International Trade (CREDIT) Research Papers.

11 DREHER, A. (2003) "Does globalization affect growth", University of Mannhheim Mimeo.

12 DURHAM, J.B. (2000) "A survey of the econometric literature on the real effects international capital flows in lower income countries", Qeh Working Paper, 50 Mimeo: University of Oxford.

13 EDISON, H.J., LEVINE R., LUCA R., \& SLOK, T. (2002) "International financial integration and economic growth", IMF Working Paper, 02/145.

14 EKPO, A.H. \& EGWAKHIDE, F. (1994) "Export and economic growth in Nigeria: A reconsideration of the evidence", Journal of Economic Management 1(1): 100-18.

15 EKPO, A.H. (1995) "Openness and economic performance in Nigeria: A time series approach", Selected Paper for the 1995 Annual Conference The Nigerian Economic Society.

16 ENOROU, E. \& AHMED, Y. (1999) “Openness and economic growth': Evidence from selected Asian countries", Indian Economic Journal, 47 (3): 110-17.

17 FOSU, A.K. (1990) "Export composition and the impact of export on economic of developing economies", Economic Letters, 34: 67-71.

18 GARRETT, G. (2001) "The distributive consequences of globalization", Indian Economic Journal, 47 (3): 110-17.

19 GRANGER, C.W.J (1969) "Investigation of causal relations by economic models and cross-spectral methods", Econometrica, 37. 
20 GRANGER, C.W.J. (1980) "Testing for causality: A personal viewpoint", Journal of Economic Dynamics Control, 2: 329-52.

21 GRANGER, C.W.J (1988) "Some recent development in a concept of causality", Journal of Econometrics 39: 199-211.

22 JIN, J.C. (2002) "Openness, growth and inflation: evidence from South Korea", Faculty of Business Administration, The Chinese University of Hong Kong Mimeo.

23 JONSSON, G. \& SUBRAMANIAN, A. (2001) "Dynamic gains from trade: Evidence from South Africa", IMF Staff paper 48(1).

24 JUN W.S. \& MARSHALL, P.J. (1985) "Export, growth and causality in developing countries", Journal of Development Economics, 18: 1-12.

25 KUNST N.M. \& MARIN, D. (1989) "On export and productivity: A causal analysis", Review of Economics and Statistics, 71: 699-703.

26 MUHAMMED, S.A. \& SAMPATH, R.K. (1999) "Exports and economic growth", Indian Economic Journal, 47(3): 79-88.

27 NIDUGALA, G.K. (1999) "Exports and economic growth in India", The Indian Economic Journal, 47(3): 67-77.

28 ODUSOLA A.F. \& AKINLO, A.E. (1995) "Trade, growth and causality in Nigeria", a Selected Paper for the 1995 Annual Conference of NES.

29 OLADIPO, O.S (1998) "Trade liberalization and economic growth in Nigeria”, Ife Social Sciences Review, 15(1): 80-92.

30 OLOMOLA, P.A. (1998) "Openness and long run economic growth in Nigeria 1960-1998", Journal of Economic Management, 5(1): 39-61.

31 SINHA, D. \& SINHA, T. (1996) "An empirical investigation into the relationship between openness and economic growth: Evidence from Asia", Rivista Internazionale Di Scienze Economiche E Commerciali, 43: 356-70.

32 SINHA, D. \& SINHA, T. (2001) "Openness, investment and economic growth in Asia", Indian Economic Journal, 49(4): 90-95.

33 ZHANG, S. (2002) "A panel study of the openness growth linkage", Department of Economics, Syracuse University Mimeo. 